\title{
IN VITRO TREATMENT OF Centrosema pubescens (Benth.) WITH SULFUR WATER AND SHEEP MANURE
}

\author{
Kaunang Ch. L. ${ }^{1}$, Pudjihastuti E. P. ${ }^{1}$ \\ ${ }^{1}$ Department of Animal Nutrition Science, Faculty of Animal Husbandry, Sam Ratulangi University, Manado, Indonesia \\ Email: charleslodewijkkaunang@yahoo.com
}

\begin{abstract}
This study was aimed to evaluate the in vitro Centrosema pubescens response treated with sulfur water and sheep manure. The experiment was conducted at Agrostology Laboratory, Department of Animal Nutrition Science, Faculty of Animal Husbandry, Sam Ratulangi University Manado. Randomized group design of 2 x 5 factorial patterns with three repetitions based on the rumen liquid collecting time was used in this research. There were two factors in this experiment; sheep manure and sulfur water. The first factors consisted of $\mathrm{o}$ ton/ha manure (A1) and 25 ton/ha manure (A2). The second factor was sulfur water that divided into 5 levels; o\% (B1), 25\% (B2), 50\% (B3), 75\% (B4) and 100\% (B5). Variables measured in this research were dry matter digestibility (DMD), organic matter digestibility (OMD), ammonia $\left(\mathrm{NH}_{3}\right)$ and Volatile Fatty Acid (VFA). In vitro nutritional evaluation performed with all variables showed both factors (sulfur water and sheep manure) had significant differences $(\mathrm{p}<0.001)$ and had no significant effect $(\mathrm{p}<0.05)$ on each variable. Interaction of both factors was very significant $(\mathrm{p}<0.01)$ ontotal VFA and DMD. From this study it can be concluded that production of $\mathrm{NH}_{3}$, VFA, total DMD and OMD showed an optimal result if treated with 25 ton/ha of sheep manure and 50\% sulfur water (39.25 ppm).
\end{abstract}

Keywords: Centrosema pubescens, sulfur water, sheep manure

\section{INTRODUCTION}

It is well known one factor that could decrease the rate of forage consumption is its protein level $(<7 \%)$. Tropical forage contains relatively less mineral (especially during dry season) hence the ruminants in the tropics tend to be mineral deficient. Forage generally contains only small amount of minerals that can not meet the mineral needs of sheep such as phosphor, sulfur, sodium and others.

Fertilizer usage is the way for farmers in improving pasture productivity. In fact most farmers applyorganic fertilizer to their pasture rather than inorganic one. This is due to the expensive price of inorganic fertilizer in addition to its negative impact on soil physicochemical properties. Therefore, the use of sulfur water and organic fertilizer especially manure become an alternative in an effort to increase the productivity of forage feed (Parakkasi, 2015). Manure is a natural fertilizer made from animal excrement which is inexpensive and has ability to maintain soil fertility through physical, chemical and biological soil improvement.

Sulfur water contains various elements such as $\mathrm{S}, \mathrm{N}, \mathrm{P}, \mathrm{K}, \mathrm{Ca}, \mathrm{Mg}, \mathrm{Fe}, \mathrm{Al}, \mathrm{Mn}, \mathrm{Cu}$ and $\mathrm{Zn}$. Sulfur water as a natural fertilizer could increase ruminant productivity indirectly through fertilization of forage feed.
Fertilizing plants with sulfur can improve the quality and quantity of pasture, which increases the soil organic N, Ca-dd and S composition (Lamond et al., 1995 and Tuherkih et al., 1998). According to Bahar (1993), treatment of $30 \mathrm{~kg} / \mathrm{ha} \mathrm{Na}_{2} \mathrm{SO}_{4}$ can significantly increase the dry matter yield of $C$. pubescens. Provision of sulfur water as a fertilizer in the forage of tropical livestock could increase the productivity of forage (Kaunang and Parakkasi, 2001). Fertilization with manure on elephant grass tends to increase the productivity of dry matter, plant growth and leaf area index (Ako, 1997).

The purpose of this research was to determine the effects of sulfur water (Lahendong hot spring, Tomohon city, North Celebes Province, Indonesia) and sheep manure treatment at different levels on nutritive value of $C$. pubescens.

\section{METHODOLOGY OF RESEARCH}

This research was conducted from June to November 2016 in Agrostology Laboratory, Department of Animal Nutrition Science, Faculty of Animal Husbandry Sam Ratulangi University. Materials and equipment used in this research were 120 C. pubescens seeds, sulfur water from Lahendong hot spring (Tomohon city), dolomite lime 5 ton / ha, sheep manure and rumen fluid (obtained from 
slaughter house).

\section{C. pubescens Planting and Sampling}

Preparation stage of planting began with collection of soil taken from surrounding research site as deep as $20 \mathrm{~cm}$ below the ground level. The soil was filtered and dried, and then supplied with sheep manure and dolomite lime. After that, we put the soil in $5 \mathrm{~kg}$ capacity polybags and planted sown $C$. pubescens with 2 pols each polybag weeks before planting.

Measurement of water capacity was done by pouring the water evenly into each polybag until the water dripped out. Polybags containing water were weighed to obtain water capacity that can be absorbed by the soil. This data was very important to know exact amount of sulfur water for watering. Provision of sulfur water is done every 3 days as much as 1800 cc each polybag. This watering method used field capacity measurement or Water Holding Capacity (WHC). Sulfur water analysis from Lahendong hot spring showed $78.51 \mathrm{ppm}$ sulfur content.

After grown for 60 days, a trimming were performed. Weeds were first harvested 40 days after the trimming. Final harvest was performed 40 days after the first harvest. Samples for $\mathrm{NH}_{3}$, volatile fatty acid (VFA), dry matter digestibility (DMD) and organic matter digestibility (OMD) analysis were obtained through composite sampling.

\section{C. pubescens Nutrition Value Analysis}

Variables measured in this analysis were production of $\mathrm{N}-\mathrm{NH}_{3}, \mathrm{VFA}, \mathrm{DMD}$ and OMD

\section{1. $\mathbf{N}-\mathrm{NH}_{3}$ analysis}

$\mathrm{N}-\mathrm{NH}_{3}$ analysis used modified micro diffusionmethod of Conway (Conway, 1958). We put $1 \mathrm{ml}$ of supernatant on the left outer cell of Conway and $1 \mathrm{ml}$ of saturated $\mathrm{Na}_{2} \mathrm{CO}_{3}$ solution in the right outer cell. The inner cell in the center was filled with $1 \mathrm{ml}$ of boric acid with bromocresol greenmethylred indicator. Then the cell was sealed with a veiled lid and then shaken for a few minutes until the supernatant mixed with $\mathrm{Na}_{2} \mathrm{CO}_{3}$. We left it for 24 hours at room temperature. Ammonia bound to boric acid was titrated with $\mathrm{H}_{2} \mathrm{SO}_{4}$ until the color turned reddish. $\mathrm{N}-\mathrm{NH}_{3}$ concentrations were calculated using following formula:

$$
\mathrm{NH}_{3}=\text { (titrated volume in } \mathrm{ml} \mathrm{NH}_{2} \mathrm{SO}_{4} \text { ) } \mathrm{mM}
$$

\section{Total VFA analysis}

This analysis used steam distillation apparatus (Siedlecka et al., 2008). $5 \mathrm{ml}$ of supernatant was fed into distillation tube. Then $1 \mathrm{ml}$ of $15 \%$ $\mathrm{H}_{2} \mathrm{SO}_{4}$ was added into the tube. The tube was closed until it vacuum and then connected with a Liebig condenser. As soon as the addition of $15 \% \mathrm{H}_{2} \mathrm{SO}_{4}$ into supernatant, the tube was directly inserted into a distillation flask containing boiling water. VFA's water vapor condensed in the condenser. The distillate was accommodated in an Erlenmeyer flask containing 5 $\mathrm{ml}$ of $\mathrm{NaOH} 0.5 \mathrm{~N}$ up to $300 \mathrm{ml}$. Into the distillate, 2 drop of phenolphthalein (PP) was added until its color changed from pink to colorless.

Total produced VFA was calculated using following equation:

Total VFA $=(a-b) \mathrm{N}-\mathrm{HCl}$ 1000/5

Note : $\mathrm{a}=$ blank titrant volume $\mathrm{b}=$ analyte titrant volume

\section{DMD and OMD}

Experiments were determined using Tilley and Terry's method (Tilley and Terry, 1963). One gram of leguminous was put into a fermenter tube plus $122 \mathrm{ml}$ of McDougall's artificial saliva at $39^{\circ} \mathrm{C}$ and $\mathrm{pH}$ 6.5-6.9 and $8 \mathrm{ml}$ of rumen fluid. Then the tube was incubated anaerobically for 24 hours in a shaker bath. After 24 hours, the tube was opened and we added $0.2 \mathrm{ml}$ of saturated $\mathrm{HgCl}_{2}$ to kill microbes. Then the tube was centrifuged at $10.000 \mathrm{rpm}$ for 10 minutes. After that, the supernatant was removed, and the precipitate was added with $0.2 \%$ pepsin solution. The tube was incubated aerobically for 24 hours. The precipitate was filtered using Whatman filter paper number 41. Then the content of DMD and OMD were analyzed.

\section{Experimental Design and Data Analysis}

This study is a randomized study using factorial pattern group ( $2 \times 5)$ with 3 repetitions based on rumen fluid collecting time (Steel and Torrie, 2013). There were two factors in this research: sheep manure and sulfur water. The first consisted of $\mathrm{o}$ ton/ha (A1) and 25 ton/ha manure (A2). The second factor was sulfur water which divided into 5 levels: o ppm (B1), $19.62 \mathrm{ppm}$ (B2), $39.52 \mathrm{ppm}$ (B3), 58.86 ppm (B4) and $78.51 \mathrm{ppm}$ (B5). Data obtained from this study were processed using analysis of variance (ANOVA) test and difference between treatments was tested further using orthogonal contrast test (SAS software).

\section{RESULTS AND DISCUSSION}

\section{Agronomic Study Results \\ Ammonia $\left(\mathrm{NH}_{3}\right)$ concentration}

The effect of manure and sulfure water on mean $\mathrm{NH}_{3}$ concentration is shown in Table 2. ANOVA test showed mean $\mathrm{NH}_{3}$ concentration ranging from $5.29 \pm 0.96 \mathrm{mM}$ to $9.46 \pm 0.19 \mathrm{mM}$. These concentrations were still within normal range. Sutardi (1986) stated that the amount of ammonia required for microbial proeun synthesis is about 4-12 mM. Ammonia 
Table 1. The effect of Manure and Sulfur Water on Crude Protein (CP) and Dry Matter (DM) of $C$. pubescens

\begin{tabular}{cccc}
\hline Sheep Manure & Sulfur water & CP (\%) & DM (gram) \\
\hline o (ton/ha) & $0 \%$ & 16.03 & 2.24 \\
& $25 \%$ & 19.11 & 2.82 \\
& $50 \%$ & 20.85 & 4.21 \\
& $75 \%$ & 19.86 & 3.27 \\
25 (ton/ha) & $100 \%$ & 20.34 & 2.78 \\
& $0 \%$ & 17.71 & 3.11 \\
& $25 \%$ & 20.18 & 3.92 \\
& $50 \%$ & 23.61 & 3.47 \\
& $75 \%$ & 21.36 & 4.72 \\
& $100 \%$ & 21.08 & 3.89 \\
\hline
\end{tabular}

released in the rumen is partially utilized by rumen microbes to synthesize microbial proteins (Sutardi and Suhartati, 1986).

ANOVA test also revealed that interaction between treatments had no significant effect $(p>0.05)$ on $\mathrm{NH}_{3}$ concentration. Meanwhile, sulfur water and sheep manure did not significantly $(p>0.05)$ affect $\mathrm{NH}_{3}$. Interaction between these two factors did not significantly ( $\mathrm{p}>0.05$ ) affect mean rumen $\mathrm{NH}_{3}$ concentration. Treatment of 25 tons/ha of sheep manure yielded higher mean $\mathrm{NH}_{3}$ concentration than without treatment $(8.32 \pm 1.34 \mathrm{mM}$ vs. $6.81 \pm 1.34 \mathrm{mM})$. Manure contains various nutrients such as nitrogen which can increase the rate of total protein production in legumes.

Table 2. Effect of Manure and Sulfure Water on Mean $\mathrm{NH}_{3}$ Concentration $(\mathrm{mM})$

\begin{tabular}{ccccccc}
\hline \multirow{2}{*}{ Manure } & \multicolumn{5}{c}{ Sulfur water } & Mean \\
\cline { 2 - 6 } & $0 \%$ & $25 \%$ & $50 \%$ & $75 \%$ & $100 \%$ & \pm SE \\
\hline o ton/ha & 5.29 & 7.00 & 6.71 & 6.17 & 6.25 & 6.81 \\
& \pm 0.96 & \pm 0.55 & \pm 0.19 & \pm 0.63 & \pm 1.06 & $\pm 1.34^{\mathrm{b}}$ \\
25 ton/ha & 7.73 & 8.13 & 9.46 & 8.26 & 8.06 & 8.32 \\
& \pm 0.96 & \pm 0.55 & \pm 0.19 & \pm 0.63 & \pm 1.06 & $\pm 1.34^{\mathrm{a}}$ \\
Mean & 6.51 & 7.57 & 9.12 & 7.49 & 7.15 & \\
$\pm \mathrm{SE}$ & $\pm 1.5 \mathrm{O}^{\mathrm{c}}$ & $\pm 0.83^{\mathrm{b}}$ & $\pm 0.62^{\mathrm{a}}$ & $\pm 1.06^{\mathrm{b}}$ & $\pm 1.26^{\mathrm{bc}}$ &
\end{tabular}

Different superscripts on the same lane or row indicate significant differences ( $p$ $<0.01$ )

Provision of sulfur water showed the highest $\mathrm{NH}_{3}$ concentration at $50 \%$ level $(9.12 \pm 0.62 \mathrm{mM})$ compared with other levels. Treatment with $0 \%$ sulfur


$\mathrm{mM})$. Sulfur has main function to increase the synthesis of sulfur-containing amino acids as well as increase production of microbial nitrogen (Duran and Komiisarczuk, 1988). Provision of sulfur water in sheep feed could increase protein synthesis and more protein breakdown produces more ammonia, thus increasing ammonia concentration (Ensminger et. al., 1990; Suhartati, 1997).

\section{In vitro VFA production}

VFA is produced by rumen fermentation and provide main energy source for livestock. VFA production could provide as a fermentation marker of organic matter in the rumen, as shown below.

Table 3. Effect of Manure and Sulfure Water on Mean VFA Production $(\mathrm{mM})$

\begin{tabular}{|c|c|c|c|c|c|c|}
\hline \multirow{2}{*}{ Manure } & \multicolumn{5}{|c|}{ Sulfur Water } & \multirow{2}{*}{$\begin{array}{c}\text { Mean } \\
\pm \text { SE }\end{array}$} \\
\hline & O\% & $25 \%$ & $50 \%$ & $75 \%$ & $100 \%$ & \\
\hline o ton/ha & $\begin{array}{c}117.16 \\
\pm 2.66^{\mathrm{b}}\end{array}$ & $\begin{array}{l}117.83 \\
\pm 2.51^{b}\end{array}$ & $\begin{array}{l}129.82 \\
\pm 1.76^{\mathrm{a}}\end{array}$ & $\begin{array}{l}125.92 \\
\pm 5.04^{\mathrm{a}}\end{array}$ & $\begin{array}{l}125.42 \\
\pm 4.65^{\mathrm{a}}\end{array}$ & $\begin{array}{l}123.23 \\
\pm 5.96^{\mathrm{b}}\end{array}$ \\
\hline n/ha & $\begin{array}{l}113.47 \\
\pm 2.59^{\mathrm{b}}\end{array}$ & $\begin{array}{l}130.03 \\
\pm 2.00^{\mathrm{a}}\end{array}$ & $\begin{array}{l}132.38 \\
\pm 2.67^{\mathrm{a}}\end{array}$ & $\begin{array}{l}131.42 \\
\pm 1.20^{\mathrm{a}}\end{array}$ & $\begin{array}{c}129 \\
\pm 10.48^{\mathrm{a}}\end{array}$ & $\begin{array}{l}127.26 \\
\pm 8.41^{\mathrm{a}}\end{array}$ \\
\hline $\begin{array}{c}\text { Mean } \\
{ }_{ \pm} \mathrm{SE}\end{array}$ & $\begin{array}{l}115 \cdot 31 \\
\pm 3.10^{\mathrm{c}}\end{array}$ & $\begin{array}{l}123.93 \\
\pm 6.98^{\mathrm{b}}\end{array}$ & $\begin{array}{c}131.10 \\
\pm 2.46^{\mathrm{ab}}\end{array}$ & $\begin{array}{l}128.67 \\
\pm 4.45^{\mathrm{ab}}\end{array}$ & $\begin{array}{c}127.21 \\
\pm 7.59^{\mathrm{ab}}\end{array}$ & \\
\hline
\end{tabular}

Different superscripts on the same line or row indicate significant differences ( $p$ $<0.01)$.

Mean concentration of VFA produced in this study range from $115.31 \pm 3.10$ to $131.10 \pm 2.46 \mathrm{mM}$. According to Sutardi (1986), this number is still in the optimal range for microbial growth which is about $80-160$ $\mathrm{mM}$. ANOVA test showed the treatment between block to VFA production was not significant ( $\mathrm{p}>0.05)$.

Post hoc analysis showed water sulfur administration has a significant influence on forage nutrition value $(\mathrm{p}<0.01)$. Sulfur water administration at $50 \%$ yielded the highest VFA production $(131.10 \pm 2.46 \mathrm{mM})$. Provision of manure at the level of $\mathrm{o}$ ton/ha and 25 tons/ha showed a significant effect (p <0.01).

ANOVA test between in vitro sulfur water and manure administration apparently yielded significant interaction $(\mathrm{p}<0.01)$. The highest VFA obtained from the treatment combination of 25 ton/ha manure and $50 \%$ of sulfur water. An optimum value of total VFA production was also found in the same treatment combination (25 ton/ha manure and $50 \%$ of sulfur water) seen in Table 1 where in the production of $\mathrm{CP}$ and DM of $C$. pubescens reached the highest value. This treatment combination provides the highest energy for microbial needs. CP will be broken down into $\mathrm{N}$ elements and carbon skeletons. These carbon skeletons are used to form VFA in the rumen, hence higher CP was expected to increase total rumen VFA production.

\section{In vitro DMD}

Digestibility coefficients of food substance reflect that DMD can be used as an indicator to determine the feed quality. Mean of DMD after manure and sulfur water treatment is shown in Table 4.

ANOVA test showed DMD coefficient ranged from $46.23 \pm 0.64 \mathrm{mM}$ to $60.83 \pm 1.01 \mathrm{mM}$. Interaction between sulfur water and manure was significant (p $<$ o.01). This showed that sulfur water and sheep 
Table 4. Effect of Manure and Sulfure Water Treatment on Mean DMD (\%)

\begin{tabular}{ccccccc}
\hline \multirow{2}{*}{ Manure } & \multicolumn{5}{c}{ Sulfur water } & Mean \\
\cline { 2 - 6 } & $0 \%$ & $25 \%$ & $50 \%$ & $75 \%$ & $100 \%$ & \pm SE \\
\hline o ton/ha & 46.23 & 56.23 & 59.43 & 57.90 & 57.06 & 55.37 \\
& $\pm 0.64^{\mathrm{g}}$ & $\pm 0.80^{\mathrm{d}}$ & $\pm 0.49^{\mathrm{ab}}$ & $\pm 0.72^{\mathrm{bcd}}$ & $\pm 0.75^{\mathrm{cd}}$ & $\pm 4.88^{\mathrm{b}}$ \\
25 ton/ha & 48.14 & 53.24 & 60.83 & 58.51 & 57.40 & 55.62 \\
& $\pm 1.57^{\mathrm{g}}$ & $\pm 1.09^{\mathrm{e}}$ & $\pm 1.01^{\mathrm{a}}$ & $\pm 1.09^{\mathrm{cb}}$ & $\pm 1.14^{\mathrm{cd}}$ & $\pm 4.74^{\mathrm{a}}$ \\
Mean & 47.19 & 54.73 & 60.13 & 58.20 & 57.23 & \\
$\pm \mathrm{SE}$ & $\pm 1.50^{\mathrm{d}}$ & $\pm 1.84^{\mathrm{c}}$ & $\pm 1.04^{\mathrm{a}}$ & $\pm 0.89^{\mathrm{b}}$ & $\pm 0.82^{\mathrm{b}}$ &
\end{tabular}

Different superscripts on the same line or row indicate significant differences ( $p$ $<0.01)$

manure treatment could affect each other. ANOVA test also revealed the highest DMD coefficient occurredat A2B3 treatment (25 tons/ha sheep manure and 50\% of sulfur water) compared to other treatments. Hume (1982) stated the forage's nitrogen and sulfur content could affect digestibility.

Manure treatment with different level (o and 25 tons/ha) showed a significant influence $(\mathrm{p}<0.01)$. This is due to manure treatment during planting will increase the soil nutrient, thus improving nutrients plant needed to grow (Islami and Utomo, 1995). Legumes have a unique capability to convert atmospheric nitrogen element as a protein constituent elements to form amino acid they needed (National Academy of Sciences, 1979).

Sulfur water administration at different levels based on ANOVA test showed a significant effect on dry matter digestibility ( $p<0.01)$. This is due to different levels of sulfur water treatment have a different effect on the composition of $C$. pubescens nutrients, resulting in different digestibility by rumen microbes.

\section{In vitro OMD}

Mean of OMD after in vitro manure and sulfur water treatment is shown in Table 5 .

ANOVA test showed the average of OMD coefficient ranged from $52.00 \pm 1.53 \mathrm{mM}$ to $69.85 \pm 1.04 \mathrm{mM}$. This test also revealed the interaction between each treatment had no significant effect ( $p>0.05$ ) on OMD coefficient. Mean of OMD coefficient showed a lower value after manure treatment of o ton/ha compared to 25 tons/ha. Post hoc analysis showed the effect of manure treatment on $C$. pubescens dry matter was significant $(\mathrm{p}<0.05)$.
Sulfur water treatment has a significant effect on OMD coefficient. This suggests that each level of sulfur water administration contributes differently to increase C. pubescens dry matter. The highest OMD was obtained at 50\% sulfur water. Sulfur treatment could increase bacterial growth rate thus increasing the food substance digestibility (Qi et al., 1992).

\section{CONCLUSION}

From discussion above, we concluded the production of $\mathrm{NH}_{3}$, total VFA, DMD and OMD reached optimum results if $C$. pubescens was treated with 25 tons/ha of sheep manure and $50 \%$ of sulfur water (39.25 ppm).

\section{REFERENCES}

Ako, A. 1997. Pengaruh tingkat pemberian pupuk kandang terhadap pertumbuhan and produksi rumput gajah (Pennisetum purpureum Schumach and Sorgum bicolor Merich). Media Vet 2:34-42

Bahar S., R. Rakhman, D. Bulo, and R. Salam. 1993. Pengaruh pemberian fosfor and belerang terhadap pertumbuhan tanaman Centrosema pubescens. Sub Balai Penelitian Ternak Gowa Jurnal Ilmiah 7:6-12

Durand,M and S. Komisarczuk.1988. Influence of major mineral on rumen microbiota.J.Nutr.118:249-260

Ensminger,M. E., J. E. Oldfield and V. M. Henemann. 1990. Feeds and Nutrition. $4^{\text {th }}$ Ed. The Ensminger Publishing Company, California.

Hume.J.D.1982. Fiber digestion in the ruminant nutrition and growth Manual. Mebourne: Hedge and Bell Pty Ltd.p.37-39

Islami, T and W. H. Utomo. 2016. Hubungan Tanah, Air and Tanaman. IKIP Semarang Press, Semarang.

Kaunang, C. L. and A. Parakkasi. 2001. Pemberian air belerang dan air keran pada $P$. maximum cv. Gatton, Brachiaria humidicola, Centrosema pubescens, Stylosanthes hamata. Prosiding Pengembangan Peternakan Berbasis Sumber Daya Lokal 8-9 Agustus 2001. Fakultas Peternakan IPB Bogor.

Lamond, R.E., A. Whitney, and B. H. Mars. 1995. Sulphur fertilization of smooth bromegrass in Kansas. Journal of Agronomy 87:13-16.

Table 5. Effect of Manure and Sulfure Water Treatment on Mean OMD (\%)

\begin{tabular}{|c|c|c|c|c|c|c|}
\hline \multirow{2}{*}{ Manure } & \multicolumn{5}{|c|}{ Sulfur water } & \multirow{2}{*}{$\begin{array}{c}\text { Mean } \\
\pm \mathrm{SE}\end{array}$} \\
\hline & O\% & $25 \%$ & $50 \%$ & $75 \%$ & $100 \%$ & \\
\hline o ton/ha & $52.00 \pm 1.53$ & $61.27 \pm 1.02$ & $67.20 \pm 1.21$ & $65.44 \pm 0.55$ & $64.71 \pm 0.71$ & $62.12 \pm 5.68^{b}$ \\
\hline 25 ton/ha & $56.96 \pm 1.01$ & $63.29 \pm 0.99$ & $69.85 \pm 1.04$ & $68.55^{ \pm 1.14}$ & $67.83 \pm 0.64$ & $64.29 \pm 4.95^{\mathrm{a}}$ \\
\hline Mean \pm SE & $54.48 \pm 2.95^{\mathrm{d}}$ & $62.28 \pm 1.43^{c}$ & $68.52 \pm 1.77^{\mathrm{a}}$ & $66.69 \pm 1.88^{b}$ & $66.27 \pm 1.81^{\mathrm{b}}$ & \\
\hline
\end{tabular}

Different superscripts on the same line or row indicate significant differences $(p<0.01)$ 
National Academy of Sciences. 1979. Tropical Legumes: Resources for the Future

Parakkasi, A. 2015. Ilmu Nutirisi dan Makanan Ternak Ruminansia. UI Press, Jakarta.

Qi, K., C. K. Lu and F. N. Owen. 1992. Sulphate supplementation of alpine goats: effects on milk yield and composition, metabolites, nutrient digestibility and acid-base balance. Journal of Animal Science 70:3541-3550

Siedlecka E.M., J. Kumirska, T. Ossowski, P. Glamowski, M. Golebiowski, J. Gajdus, Z. Kaczynski, P. Stepnowsky. 2008. Determination of volatile fatty acids in environmental aqueous samples. Polish Journal of Environmental Study 17: 351-356

Steel, R. G. D. and J. H. Torrie. 1980. Principles and Procedures of Biostatistics. McGrawHill, New York.
Suhartati, F. M. 2015. Manfaat air belerang dalam ransum bagi domba muda. Disertasi. Institut Pertanian Bogor, Bogor.

Sutardi, T. 1986. Ketahanan protein bahan makanan terhadap degradasi oleh mikroba rumen and manfaatnya bagi produktivitas ternak. Prosiding Seminar and Penunjang Peternakan. Lembaga Penelitian Peternakan, Lembang.

Tilley and Terry. 1966. General Laboratory Procedure. Department of Dairy Science University of Wisconsin, Wisconsin.

Tuherkih, E., I. G. P. Wigeno, J. Purnomo and D. Santoso. 1998. Pengaruh pupuk belerang terhadap sifat kimia tanah and hasil hijauan pakan ternak pada padang penggembalaan. Prosiding pertemuan pembahasan and komunikasi hasil penelitian tanah and agroklimat bidang kimia and biologi tanah. Hal. 283-291 